\title{
EFFECTIVENESS OF APPLYING PRINCIPLES OF LEGAL CERTAINTY OF JUSTICE IN THE HANDLING OF CRIMINAL CASE
}

\author{
Elif Acar \\ Head of Turkish Student Association in Angkara University, Turky \\ Elf acar@gmail.com \\ Sugeng Sudrajat \\ Judge at the Court of Singkawang \\ ddrajad7@gmail.com
}

\begin{abstract}
The effectiveness of judges' verdict in the trial should ideally contain aspects of the rule of law, justice and expediency. In its implementation is not easy to synergize these three aspects, especially the aspect of legal certainty and fairness are usually contradictory. The results showed that the judge in examining and deciding cases not forever fixated on one principle alone. Constraints faced by judges tend to rule of law in deadlock when written provisions can not answer the problems that exist. Emphasis is more inclined to the principle of justice means should consider a law in society, which is made up of customs and unwritten laws. Judge within reason and legal considerations must be able to accommodate all the provisions that live in the community in the form of customs and unwritten laws. Emphasis tends to be on the principle of expediency over economic nuances.
\end{abstract}

Keywords: Effectiveness, Justice, Legal Certainty,

\section{A. INTRODUCTION}

Effective word comes from the English that is effective, which means success or done something successful. Efetivitas popular scientific dictionary defines as the accuracy of the use, effectiveness or support purposes. According to Indonesian dictionary, effectively is something that no effect (consequently, influence, impression) since starting the enactment of a law or regulation. ${ }^{1}$

While the effectiveness itself is a state where he played for monitoring. When viewed from the point of law, which is meant by "he" here is that the police authorities. The word itself

1 Edy Herdyanto, Kebijakan Penyelenggaraan Kekuasaan Kehakiman Sebagai Kendali Pembentukan Pengadilan Khusus Di Indonesia, Jurnal Yustitia, Vol. 72. September-Desember 2007. Surakarta: FH Universitas Sebelas Maret 
comes from the effectiveness of effective word, which means there is a desired effect or result in an act. Any work efficiently means effective as seen from the results in terms of the goal or desired from the deed ${ }^{2}$.

Basically, the effectiveness of a degree of success in achieving goals. Effectiveness is a measure in the sense of achievement of goals or objectives that had been predetermined. In sociology of law, the law has a function as a tool of social control is an attempt to achieve a balanced condition in society, which aims at the creation of a harmonious state between stability and change in society. In addition the law also has another function, namely as a tool of social engineering by which he meant as a means of renewal in society. Law can play a role in changing the mindset of people from traditional thinking patterns into patterns of rational thought or modern. Effectiveness of law is a process that aims so that the law became effective.

When we wanted to know the extent to which the effectiveness of

${ }^{2}$ Goesniadhie Kusnu S, Perspektif Moral Penegakan Hukum Yang Baik, Jurnal Hukum Ius Quia Iustum. Vol. 17 No. 2. April 2010. Yogyakarta: FH UII. the law, then we must first be able to measure the extent to which the law was obeyed by most of the targets that were targeted obedience, we will say that the rule of law in question is effective. However, even if the rules are adhered to say it's effective, but we still can be questioned further degree of effectiveness due to someone to obey or not a rule of law depends on their interests. As mentioned earlier, that the interests of the existing assortment, among which are compliance, identification, internalization ${ }^{3}$.

Political law as legal development policy should be used as a measure to be able to see results that have been achieved by the construction of the current law. Law enforcement is one of the major milestones in the country even placed as a separate section in the legal system. Law enforcement lead to any existing dispute to be settled, 3 whether it disputes among fellow citizens, between citizens and the state, country to country, therefore,

${ }^{3}$ Hartini, Pengecualian Terhadap Penerapan Asas Ultra Petitum Partum Dalam Beracara di Pengadilan Agama, Jurnal Mimbar Hukum. Vol. 21 No. 2; Juni 2009; Yogyakar-ta: FH UGM. 
the rule of law is a necessary condition for the creation of state enterprises and peaceful of Indonesia.

The essence and meaning of the rule of law, conceptually, lies in activity relationships which span the 'hierarchy of values in the rules that exist in masyara-kat order to preserve and maintain. The law enforcement process, that is the implementation of the rules which apply in society ${ }^{4}$.

Basically, the law enforcement can begin them with attention of law enforcement. The key point in good law enforcement on principles in there. It is also the case with the judge in achievement of law enforcement characterized by all justice, legal certainty and benefit of justice.

The assertion was contained also in the Judicial Authority Law which provides that the judicial power is independent of state power for convened court to uphold law and justice. Existing legal fact generally show his distrust of the judiciary, because one of the main factors that the judge's decision not to digest the outflow value rule of law, justice and all that is coveted utilization.
Conditions are still deplorable judicial authority, in accordance with what was described by Kanter that, "if you do not want to lose buffalo-byinterrupt a goat, do not you backing to the court process" Statement of the show distrust Kanter search justice to the law enforcement in this country ${ }^{5}$.

The judge has the goal to uphold truth and justice as well as the duties shall always uphold the law. Life is not justified to actions that are not in accordance with the norms of honor and must have a behavior that does not deform. According Otong Rosadi, however, requires moral law, throughout the days of the empire (quid certification fee, certification fee of sine moribus) what it means to act if not accompanied moralitas. Judge in the judicial process has a big responsibility to the community in the delivery of the decisions that reflect the rule of law and justice and expediency so that justice be a nurturing hopes and desires of the community ${ }^{6}$. Jakarta. 
The judge, as judicial officials who carry out judicial proceedings, including judicial proceedings ta regulations, it would certainly have a great responsibility towards the birth of decision. Generated by the judges in the court idea does not pose a new problem in society, which means that the quality of the judge's decision an important effect on the environment and affected communities innate and credibility of the judiciary itself. In reality there are still many verdict in the proceedings that the juice-tru create polemics bears a new and care of the problem.

\section{B. RESEARCH METHODS}

This research is a normative juridical namely legal research aims to find code, norms or das sollen. Code understanding in this regard include the principle of law, legal norms, the legal system and rule of law to all devices in particular concrete legislation?.

In accordance with the object of study that is the norm of law, this study based on the availability of secondary law. In this regard, Sudikno

7 Muhammad Rusli, Strategi Dalam Membangun Kembali Kemandirian Pengadilan Di Indonesia, Jurnal Hukum Ius Quia Iustum, Vol. 25 No. 11. April 2004. Yogyakarta.
Mertokusumostates in an effort Complete Data (legal materials) obtained from the research literature can be equipped with field research ${ }^{8}$. According to Pieter Mahmud Marzuki legal materials constitute official documents in the form of all the publicity about the law. Publication of the law include legislation, regulation of Government, textbooks, dictionaries law, legal journals, and comments on the court decision. Materials such law, then can be divided into three (3) groups of parts, namely: primary legal materials, secondary law and tertiary legal materials. Secondary legal materials obtained through the document study is to collect and analysis verdict of criminal justice.

To complete the legal materials do also research field. The data obtained are primary data. The determination of resource persons conducted by directly pointing the parties are considered competent to download the appropriate answer questions. While respondents are limited only to those who have been involved directly with the problems examined. 
This research was conducted at several locations, with details of the location of the research which is as follows: South Jakarta District Court. Yogyakarta District Court, the Manado District Court, District Court and the District Court Boalemo Limboto any region of Gorontalo province. Besides PN has do also research at PT Jakarta, PT Yogyakarta, North Sulawesi PT and PT Gorontalo. The analytical method used in this research is qualitative analysis. Qualitative analysis method is procedure that produces descriptive data.

\section{RESEARCH RESULT AND DISCUSSION}

Basically the court decision must be able to and dare heart of society. Courts in doing work functions and duties in accordance with their conscience and dreams of the people ${ }^{9}$. Oversight Institution not only be the engine of the legislation, but also able to observe the life of the nation as intense.

Indeed, the judge's decision is needed to resolve a case that he-has put forward to the court. Decisions of judges should be able to resolve the case filed, lest it exacerbate the problem, even it caused controversy among legal practitioners and the general public. Causing controversy exists verdict was the one judge who did not master the state of laws rapid development in accordance with developments of era, as well as less rigorous influenced by the judge to determine the process of taking a case.

The judges' verdict should contain several aspects. First, the judge's ruling Meru-feed overview of the process of social life as part of the process of social control; second, breaking late judge is the embodiment of law and essentially useless for each person or group and also the state; Third, the judge's ruling is a picture of the balance between the provisions of the law with the reality on the ground; Fourth, the judge's ruling is a picture of an ideal awareness between law and social change, the fifth, the judge's ruling should be beneficial to all litigants; sixth, judge's decision does

9 Rosadi, Otong, Hukum Kodrat, Pancasila dan Asas Hukum dalam Pembentukan Hukum Di Indonesia, Jurnal Dinamika Hukum. Vol. 10 No. 3. September 2010, Purwokerto: FH Universitas Jenderal Soedirman. 
not lead to new conflicts for the litigants and the public ${ }^{10}$.

The judges' verdict is the result of court proceedings. While the court itself as the last refuge for the seekers of justice, and therefore the judge's decision in a court of course must be filled the what is demanded by the justice seeker. Thus, the judge in deciding a case still starts on the third element of the rule of law, justice and all utilization ${ }^{11}$.

\section{Reflecting The Judge Verdict Legal Certainty}

The judge in settling cases per the data in court, has the task to appropriate law. The judge, is not enough to look for in the statute, because the possibility of legislation does not set out clear and Legal values that live in the ma-syarakat other no customary law and unwritten law. The judge served as penggalinya and formulating it into a decision. Decision of judges are part of the process laws enforcement

10 Sufriadi, Yanto, Penerapan Hukum Progresif Dalam Pemulihan Krisis Hukum Di Tengah Kemacetan Demokrasi di Era Global, Jurnal Hukum Ius Quia Iustum. Vol. 17 No. 2. April 2010.nYogyakarta: FH UII.

11 Wantu, Fence M. Antinomi Dalam Penegakan Hukum Oleh Hakim, Jurnal Mimbar Hukum. Vol. 19 No. 3. Oktober 2007. Yogya-karta: FH UGM. aimed to achieve one legal truth or for the sake of legal certainty form. The judges' verdict is law enforcement product that is based on things that are relevant law from the process of legally court. Legal considerations used by the judges as the basis in issuing the verdict is determinant in viewing quality decision.

Ideally, in order to implement the rule of law, the judge's decision shall be in accordance basis of a court, containing the rule of law as follows: first, do solution authoritative, meaning that the way out of the legal problems faced by the parties (plaintiff and defendant); the second, efficiency means that the process must be hurry, simple, low cost; Third, appropriate with goal that made laws of the judge's ruling; fourth, stability aspect that can give sense of order and security in society; fifth, containing eguality which backs give equal opportunity for litigants ${ }^{12}$.

Legal certainty as outlined in the judge's decision is the result that is based on facts relevant 
proceedings throughout juridical ways and considered by conscience. Judges are always required to always be able to interpret the meaning of the laws and other regulations which serve as the basis for implementation. Application of the law should be appropriate with case, so the judge can construct a case heard in their entirety, thoughtful and objective ${ }^{13}$.

The judges' verdict that contains elements of the rule of law will contribute to the development of science in the field of law. This is due to the decision of the judge who already has permanent legal force, is no longer the opinion of the judges themselves who decide case, but it is the opinion of the judiciary and become society in daily life.

In connection with the verdict that reflects the legal certainty necessary to analysis of one sample Decision Oversight South Jakarta District No. 1145 / Pdt.G / 2004 / PN.Jak.Sel, the lawsuit Request Cancel Determination of No 61 /

13 Wijayanta, Tata dan Heri Firmansyah, Perbedaan Pendapat Dalam Putusan-Putusan Di Pengadilan Negeri Yogyakarta Dan Pengadilan Negeri Sleman, Jurnal Mimbar Hukum. Vol. 23 No. 1. Februari 2011, Yogyakarta: FH UGM.
Pdt.P /2004/PN.Jaksel. and the establishment of a legal guardian of the child out of wedlock ${ }^{14}$.

That Plaintiffs are citizens of Indonesia, while the Defendant is a citizen of Australia. The relationship that Plaintiffs and Defendants have boy named Martin Javier age of 9 (nine) years, based on Birth Certificate or Birth Certifica-ted No. S9526052G published by Thomsom Medical Center (Exhibit P 3). That the relationship between the Plaintiff and have separate Ter-jerk around December 2001. Whereas according to the positive law in Indonesia regarding children born out of wedlock, the child only has a blood relationship with her mother is not her father. That apparently unnoticed by the Plaintiff, the Defendant has made a late Petitioners Trusts and also recognition of children through the Registrar's Office Ne-geri Court of South Jakarta,

Judges hear this case backs provide core legal reasoning is basically as follows:

14 Kanter, 2000, "Etika Profesi Hukum: Sebuah Pendekatan Sosio-Religius". Cetakan Per-tama, Storia Grafika, Jakarta. 
The verdict of this case check-point se contain elements of justice and Utilization of all, however, the emphasis le-bih on legal certainty. Fulfillment of formal elements of justice, especially justice in per-kara is nothing that because of his ha Plaintiff questioned and would like to ask the judge to cancel on the determination of the South Jakarta District Court No. 61 / Pdt.P / 2004 PN.Jak.Sel March 11, 2004. While fulfillment element of expediency in this case is the decision of the judges in this case very beneficial for both parties, because the decision of the judges concerning child custody status has been able to know for sure who exactly is entitled to the child. Moreover, this decision does not only bring benefits all on both sides, but also influential in case the decision which will appear later in life.

The judges' verdict in this case, according to writer ratings favors the fulfillment elements of the rule of law does not mean attention to justice and expediency. Basically the decision of the judges have noticed these three elements ie all legal certainty, fairness and expediency, but said the emphasis more towards all the legal uncertainty. It also can be understood by looking at what is the object of the plaintiff for the cancellation determination Jak PN. Cells No. No. 61 / Pdt.P / 2004 PN.Jak.Sel.

Focused on the case, it can be said of legal certainty requires so making procedure for legislation should clear and known by the general public. Legal certainty is also demanding that the law be built sustainably and consistently.

\section{Reflecting Judge Justice ruling.}

Indeed, the concept of a decision containing justice, extremely difficult to overcome for the parties to the dispute. Fair for one party, not necessarily perceived as fair by the other party.

This is consistent with decision, which reads: "For the sake of justice Based on God". In doubtenforcing the verdict reflects the justice, the authors analyze one of the judge's decision in the District Court Tilamuta No. 01 / Pdt.G / 
2008 / PN.TLM the deeds of the law enjoy the fruits of the object of dispute that have been sold traded $^{15}$.

Analysis of the law that the verdict in reflects elements of justice, because the judges have recognized the equality of rights and obligations for both parties, judges have applied the compatibility between the existing regulations with the decision of the judge, and the judge's decision has been appropriate community wants justice, the winning party can demand what exactly they are entitled and the losers meet what was his duty.

The judge's decision is more emphasis to elements of justice, it does not mean that the rule of law and no benefit, legal certainty and expediency element remains in the judge's decision. Fulfillment of all elements can be seen as legal uncertainty this decision has provided a way out of the legal issues for both parties, has judge's decision based on the law, and has provided equal opportunities for litigants. While the element of expediency fulfillment of this decision has created for litigants, ledge polemics or conflicts for which regain the winning side of what was owed.

Based on the cases described above, in order and efforts to find and do justice, the judge's decision in court should be in accordance with the true purpose, namely: first, the decision of the judge must conduct a solution authoritative, meaning that the way out from legal problems by the parties (plaintiff and defendant); second, the decision ha should contain efficiency, ie fast, low cost, because justice delayed is injustice; Third, the judge's ruling should be in accordance with the purpose of the legislation that formed the basis of the court decision; fourth, the verdict must has stability aspect, namely social order and public tranquility; and fifth, decision of judge there must be fairness, which

15 Mahyuni, Lembaga Damai Dalam Proses Penyelesaian Perkara Perdata Di Pengadilan, Jurnal Hukum Ius Quia Iustum, Vol. 16 No. 4. Oktober 2009. Yogyakarta: FH UII. 
gives all the opportunity of the same for the party ${ }^{16}$.

Fair intrinsically meaningful things in place and give to anyone what is rightfully his, which is based on a principle that throughout people are equal before the law. Emphasis is more inclined to the principle of justice can mean having to consider the laws that live in the community, which consists of habits and all contingencies unwritten law. Judge within reason and legal considerations must can accommodate any provisions that live in the community in the form of customs and unwritten laws, when me promiscuous principles of justice as a basis to decide faced.

\section{Judge's decision that reflects the usage}

The judges' verdict will reflect the benefit, not only when the judge textual law and only pursue justice alone, but also leads to a benefit for the interest of the litigant parties and the interests of society in general. This means that judges apply the law, let weigh the outcome, whether the judge broke up late to-benefit or usage for all parties. The judge is expected to adopted laws or existing laws based on objective or keman-faatannya for litigants and society.

Given the judge's decision is law, the judge must maintain in the community by means of restoring public order in the first state (restitutio in integrum. Community expects the settlement through court that will bring benefit or usefulness to the common life in the society. Hope at least judge decision to restore the balance of society, which means that the guilty parties are penalized, while the indisadvantaged party will receive compensation or to get what they are entitled ${ }^{17}$.

To find out the verdict that reflects the shape of expediency, need right analysis of the implementation of the verdict in the Yogyakarta District Court No. 48 / Pdt.G / 2006 / PN.Yk, about divorce in the marriage bond.

16 Butarbutar, Elisabet Nurhaini, Konsep Keadilan Dalam Sistem Peradilan pidana, Jurnal Mimbar Hukum Vol. 21 No. 3. Juni 2009. Yogyakarta: FH UGM. 
Analysis of the law that the ruling judge who examine this case has met expediency, because it has been in accordance with the expediency criteria, which has provided all the Courant or satisfaction for the parties litigant, has overcome a polemic or a new conflict to the parties, the normal circuit between parties, in-obtain it back in what became the object of the dispute by the parties declared victory, and has created a balance in society.

District Court Judge's decision, when examined in clear, actually have had an element of expediency. Elements of expediency in this decision can be seen from the desire of each party, both the Plaintiff and Defendant are no longer able to maintain the marriage, because often quarrel or dispute arises. Other, communication between the plaintiff and accountability is not there anymore, so it is very difficult to be reunited in the bond's intermarried. It must be recognized that a divorce is an action or a selection of the most severe in marriage, but because marriage is already untenable, then the consequences for the business- divorce lawsuit can be true ${ }^{18}$.

The judge's ruling that more found expediency does not mean the rule of law and justice have been ignored. Legal certainty and justice remain in the judge's decision, namely the rule of law to have provided a way out of the legal problems faced by the parties and this decision is in conformity with the legislation. Justice referred to in the decision of the judges that the equation rights and obligations and the winning side of demanding their rights as well as the losing party to fulfill its obligations.

Various civil matters as te the one previously described, can be taken gathering of that judge in examining and deciding cases not forever fixed on the principle. Judge, in each case in casuistry, could only immutable of principle that one principle to another.
18 Hartini, Pengecualian Terhadap Penerapan Asas Ultra Petitum Partum Dalam Beracara di Pengadilan Agama, Jurnal Mimbar Hukum. Vol. 21 No. 2; Juni 2009; Yogyakarta: FH UGM. 
The judge must consider pertimbang's law with good reason, why in certain cases had to pick on one principle. Thus the quality of the judge's decision can be judged from the weight reasons and the law used in case.

A judge, with good reason, to decide when to be closer to all the legal uncertainty and when closer to justice. Basically, the principle of expediency air-movement between the point of legal certainty and fairness point, where the judge is looking at the destination or purpose of the law to the public. Essentially the law created to protect human interests.

The emphasis of the principle of legal certainty by judges are more likely to maintain a written legal norms of the existing positive law. Legislation sake of legal certainty. Constraints faced by judges tend to rule of law in deadlock when written host can not answer the problems that exist. In such a situation must find to fill the law. The emphasis is more inclined principle of expediency over economic nuances ${ }^{19}$. The rationale that the law is to human or crowds, therefore the aim of the law should be useful for humanity.

The judges' verdict in criminal justice, can thus be said to have to digest the third outflow principle of the rule of law, justice and expediency. However, in each of the judge's decision is no specific emphases of the three principles. Each judge's decision that reflects the rule of law does not mean principles of fairness and expediency, fairness and usefulness remain just that the emphasis is more inclined the certainty of law. Likewise verdict shortly justice reflect not mean have legal certainty and expediency, legal certainty and expediency principle is reflected in the decision of the judge, but right over the principle of fairness. Reverse is also when the verdict was shortly reflect accommodate expediency does not mean the rule of law and justice. The principle of legal certainty and justice remain, 
only the judge's decision is more con-dong on expediency.

\section{CONCLUSION}

A judge in examining and always the case fixated on principle alone. In every case, the judge can only immutable of principle that one principle to another. Judges should note backing the legal considerations with good reason, why in certain cases have to choose one of the principles. Thus quality of judge's decision can be judged from the weight reasons and considerations used in the case law.

A judge, with good reason, to determine when to be closer to the rule of law, and when closer to justice. Basically, the principle of expediency air-movement between the point of legal certainty and fairness point, where the judge is looking at the destination or purpose of the law to the public. Essentially the law created to protect human interests.

The emphasis on the principle of legal certainty, resulting in more judges tend written legal norms of the existing positive law. Laws and regulations are enforced for the sake of legal certainty. The obstacles faced by judges who tend to emphasize the legal certainty which judges would get stuck when the written provisions can not answer the problems that exist. In such situations, the judge must find to fill the law. Emphasis is more inclined to the principle of justice can mean having to consider the law of life in society, consisting of customs and unwritten laws. Judge within reason and legal considerations must be able to accommodate all the provisions that live in the community in the form of customs and unwritten laws. The emphasis is more inclined principle of expediency over economic nuances. The rationale that the law is for humans or the people, therefore the aim of the law should be air in order to transform the human or crowds. 


\section{BLIBLIOGRAPHY}

\section{Books:}

Butarbutar, Elisabet Nurhaini. "Konsep Keadilan Dalam Sistem Peradilan pidana". Jurnal Mimbar Hukum Vol. 21 No. 3. Juni 2009. Yogyakarta: FH UGM

Goesniadhie, Kusnu S. "Perspektif Moral Penegakan Hukum Yang Baik". Jurnal Hukum Ius Quia Iustum. Vol. 17 No. 2. April 2010. Yogyakarta: FH UII

Hartini. "Pengecualian Terhadap Penerapan Asas Ultra Petitum Partum Dalam Beracara di Pengadilan Agama". Jurnal Mimbar Hu-kum. Vol. 21 No. 2; Juni 2009; Yogyakar-ta: FH UGM

Herdyanto, Edy. "Kebijakan Penyelenggaraan Kekuasaan Kehakiman Sebagai Kendali Pembentukan Pengadilan Khusus Di Indo-nesia". Jurnal Yustitia. Vol. 72. SeptemberDesember 2007. Surakarta: FH Uni-versitas Sebelas Maret

Indah, C Maya S. "Mewujudkan Sistem Peradilan Berwibawa Di Indonesia". Jurnal Media Hukum. Vol. 14 No. 3. November 2007. Yogyakarta: FH UMY

Kanter. 2000. "Etika Profesi Hukum: Sebuah Pendekatan Sosio-Religius". Cetakan Per-tama. Jakarta: Storia Grafika

Mahyuni. "Lembaga Damai Dalam Proses Penye-lesaian Perkara Perdata Di Pengadilan". Jurnal Hukum Ius Quia Iustum. Vol. 16 No. 4. Oktober 2009. Yogyakarta: FH UII

Marzuki, Pieter Mahmud, 2006. Penelitian Hukum. Cetakan Kedua Mei. Jakarta: Prenada Media Group

Muhammad, Rusli. "Strategi Dalam Membangun Kembali Kemandirian Pengadilan Di Indonesia". Jurnal Hukum Ius Quia Iustum. Vol. 25 No. 11. April 2004. Yogyakarta

Rosadi, Otong. "Hukum Kodrat, Pancasila dan Asas Hukum dalam Pembentukan Hukum Di Indonesia". Jurnal Dinamika Hukum. Vol. 10 No. 3. September 2010. Purwoker-to: FH Universitas Jenderal Soedirman

Sufriadi, Yanto. "Penerapan Hukum Progresif Dalam Pemulihan Krisis Hukum Di Tengah Kemacetan Demokrasi di Era Global". Jur-nal Hukum Ius Quia Iustum. Vol. 17 No. 2. April 2010. Yogyakarta: FH UII

Wantu, Fence M. "Antinomi Dalam Penegakan Hukum Oleh Hakim". Jurnal Mimbar Hu-kum. Vol. 19 No. 3. Oktober 2007. Yogya-karta: FH UGM

Wijayanta, Tata dan Heri Firmansyah. "Perbe-daan Pendapat Dalam Putusan-Putusan Di Pengadilan Negeri Yogyakarta Dan Penga-dilan Negeri Sleman". Jurnal Mimbar Hukum. Vol. 23 No. 1. Februari 2011. Yogya-karta: FH UGM 